\title{
Pengaruh Pengungkapan Corporate Social Responsibility Pada Nilai Perusahaan Dengan Kinerja Lingkungan Sebagai Pemoderasi
}

\author{
Ngakan Made Dwi Purawan ${ }^{1}$ \\ Fakultas Ekonomi dan Bisnis \\ Universitas Udayana, Indonesia \\ Email: ngakanpurawan@gmail.com
}

\author{
Made Gede Wirakusuma ${ }^{2}$ \\ Fakultas Ekonomi dan Bisnis \\ Universitas Udayana, Indonesia
}

\begin{abstract}
ABSTRAK
Penelitian ini bertujuan mengetahui pengaruh pengungkapan Corporate Social Responsibilty pada nilai perusahaan dan mengetahui kinerja lingkungan memoderasi pengaruh pengungkapan Corporate Social Responsibilty pada nilai perusahaan di Bursa Efek Indonesia. Penelitian ini dilakukan pada perusahaan sektor perkebunan kelapa sawit yang terdaftar di Bursa Efek Indonesia periode 2014-2018. Sampel pada penelitian menggunakan teknik purposive sampling. Teknik analisis yang digunakan adalah teknik Moderated Regression Analysis (MRA). Hasil penelitian menunjukan bahwa Corporate Social Responsibilty tidak berpengaruh terhadap nilai perusahaan. Hal ini menunjukan bahwa meskipun perusahaan telah mengungkapkan CSR, belum menjamin kenaikan nilai perusahaan. Kinerja lingkungan tidak mampu memperkuat pengaruh pengungkapan Corporate Social Responsibilty pada nilai perusahaan. Hal ini menunjukan bahwa item kinerja lingkungan tidak sesuai dengan pengungkapan CSR yang dilakukan oleh perusahaan.
\end{abstract}

Kata Kunci: CSR; Nilai Perusahaan; Kinerja Lingkungan.

\section{The Effect of Corporate Social Responsibility Disclosure on Firm Value with Environmental Performance as a Moderating}

\begin{abstract}
This study aims to determine the effect of Corporate Social Responsibility disclosure on company value and determine environmental performance moderating the effect of Corporate Social Responsibility disclosure on company value on the Indonesia Stock Exchange. This research was conducted on oil palm plantation sector companies listed on the Indonesia Stock Exchange in the 2014-2018 period. The sample in this study used a purposive sampling technique. The analysis technique used is the Moderated Regression Analysis (MRA) technique. The results showed that Corporate Social Responsibility did not affect the value of the company. This shows that even though the company has revealed CSR, it does not guarantee an increase in the value of the company. Environmental performance is not able to strengthen the effect of Corporate Social Responsibility disclosure on firm value. This shows that the items of environmental performance do not match the CSR disclosures made by the company.
\end{abstract}

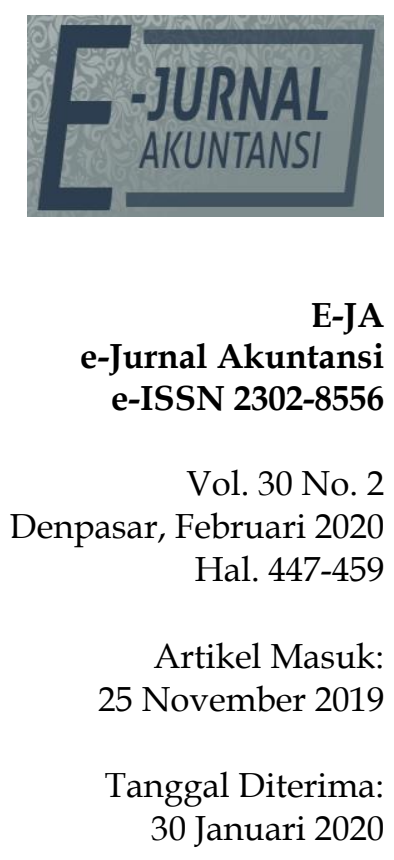

Keywords: $\quad$ CSR; Company Value; Environmental Performance. 


\section{PENDAHULUAN}

Perusahaan bertujuan untuk memperoleh keuntungan, namun dalam mencapainya perusahaan cenderung mengesampingkan ataupun melanggar moral dan etika yang dapat membahayakan keberlangsungan lingkungan maupun perusahaan. Perusahaan yang hanya berorientasi pada tujuan jangka pendek tanpa memperhatikan dampak jangka panjang cenderung akan terancam tidak mampu bertahan dimasa depan. Sebuah perusahaan yang baik harus mampu mengontrol potensi finansial maupun potensi non finansial di dalam meningkatkan nilai perusahaan untuk eksistensi perusahaan dalam jangka panjang(Sabatini \& Sudana, 2019). Pemilik modal dan masyarakat tidak hanya menilai perusahaan dari kinerja keuangannya saja, namum mereka juga memperhatikan kinerja lingkungan perusahaan. Perusahaan diharuskan melakukan tanggung jawab sosial dan lingkungan kepada masyarakat sekitar yang diakibatkan dari adanya perusahaan tersebut. Perusahaan harus mampu menyeimbangkan antara tujuan ekonomi dengan tanggung jawab lingkungan dan sosialnya agar dapat diterima baik oleh masyarakat (Lingga \& Wirakusuma, 2019). Pasar mempercayai nilai perusahaan yang tinggi bukan hanya dikarenakan kinerja keuangan perusahaan saat ini, namun juga disebabkan oleh prospek perusahaan di masa mendatang. Kinerja perusahaan yang baik tercermin dari nilai saham perusahaan yang dipasarkan di pasar saham.

Nilai perusahaan adalah persepsi pemegang saham terhadap keberhasilan perusaahaan yang sering dikaitkan dengan harga saham (Sujoko \& Soebiantoro, 2017). Menurut Noerirawan (2012) nilai perusahaan merupakan kondisi yang telah dicapai oleh suatu perusahaan sebagai gambaran dari kepercayaan masyarakat terhadap perusahaan setelah melalui suatu proses kegiatan selama beberapa tahun, yaitu sejak perusahaan tersebut didirikan sampai saat ini. Nilai perusahaan yang tinggi tidak diperoleh dengan singkat, namun harus melalui tahapan yang lama sampai perusahaan itu dapat diterima dan dipercaya oleh masyarakat. Apabila perusahaan memiliki citra yang baik dimata masyarakat, maka perusahaan akan dapat meningkatkan loyalitas konsumen terhadap perusahaan, sehingga secara tidak langsung akan meningkatkan nilai perusahaan (Nahda \& Harjito, 2011).

Perusahaan dari sektor pertambangan dan perkebunan akan cenderung memiliki dampak yang negatif terhadap lingkungan. Salah satunya adalah perusahaan perkebunan kelapa sawit yang sebagian besar aktifitasnya bergantung pada penggunaan lahan. Menurut Greenpeace (2018), sejak tahun 2015 sebanyak 130.000 hektar kawasan hutan yang hancur akibat defortasi. Industri sektor kelapa sawit dan bubur kayu menjadi pemicu kerusakan hutan ini. Sedangkan menurut Pihak Parlemen Uni Eropa, Indonesia dianggap menggunakan cara produksi kepala sawit yang tidak benar atau tidak sesuai dengan standar produksi Uni Eropa, pihak Parlemen Uni Eropa menduga Indonesia sering melakukan pembakaran hutan demi membuka perkebunan kelapa sawit (European Parliament, 2017 dalam Kumparan, 2019).

Namun dari sisi ekonomi, perusahaan perkebunan kelapa sawit memiliki peranan yang penting bagi perekonomian Indonesia dalam memenuhi konsumsi masyarakat maupun untuk diekspor. Gabungan Pengusaha Kelapa Sawit Indonesia (Gapki) mencatat produksi sawit tahun 2018 mencapai 47,43 juta ton 
dan ekspor minyak kelapa sawit dan turunannya sebesar 34,71 juta ton. Hal ini mengindikasikan komoditi kelapa sawit masih memiliki peranan yang penting dalam perekonomian Indonesia.

Perusahaan perkebunan kelapa sawit bagaikan dua mata pisau, disatu disisi kelapa sawit meningkatkan devisa negara dan disisi lainnya kelapa sawit juga meningkatkan kerusakan hutan. Berdasarkan laporan World Wide Fund for Nature (WWF) berjudul The Environmental Status of Borneo 2016, salah satu pendorong utama penggundulan hutan disebabkan ekspansi perkebunan kelapa sawit. Pada 2015, luas lahan perkebunan kelapa sawit di Kalimantan sudah mencapai 7 juta hektare, atau 10 persen dari luas Kalimantan. Persoalan sawit juga bukan hanya di Kalimantan saja, namun juga pada pulau Sumatera. Hampir setiap tahun kasus pembakaran lahan dan hutan terjadi salah satunya ekspansi bisnis sawit. Rusaknya hutan ancaman serius bagi spesies yang terancam punah seperti Gajah Kerdil Borneo, Gajah Sumatera, Harimau Sumatera, Badak Sumatera, dan spesies Orangutan.

Permasalahan inilah yang memunculkan kesadaran dari perusahaan untuk mengurangi dampak negatif yang terjadi akibat kegiatan produksinya. Upaya yang dilakukan untuk mengurangi dampak negatif yang diakibatkan perusahaan, maka perusahaan melakukan kegiatan Corporate Social Responsibility (CSR) atau sekarang disebut tanggung jawab sosial. Berdasarkan UU No.40 Tahun 2007 mengenai Perseroan Terbatas, maka suatu perusahaan khususnya perseroan terbatas diwajibkan untuk melaksanakan tanggung jawab sosial kepada masyarakat. Tanggung jawab sosial atau Corporate Social Responsibility (CSR) adalah kontribusi perusahaan kepada masyarakat dan lingkungan sekitar atas profit yang didapatkan perusahaan yang berasal dari aktivitas bisnis (Risa et al., 2011). Aktivitas bisnis perusahaan sering kali menimbulkan kerusakan lingkungan dan dampak sosial bagi masyarakat sekitar. Apabila perusahaan melakukan tanggung jawab sosial sesuai aturan yang ditetapkan, perusahaan akan dapat meminimalisir klaim dari masyarakat dan pemerintah serta citra dan nilai perusahaan yang pada akhirnya akan dapat meningkatkan keuntungan ekonomi (Lingga \& Wirakusuma, 2019).

Beberapa penelitian tentang pengaruh pengungkapan Corporate Social Responsibility (CSR) pada nilai perusahaan menemukan hasil yang tidak konsisten, seperti, penelitian yang dilakukan oleh Rosiana et al., (2013), Nurani (2015) dan Ratnadewi (2016) dalam penelitiannya menyatakan hasil bahwa penggungkapan Corporate Social Responsibility berpengaruh positif pada nilai perusahaan. Hasil penelitian tersebut berbeda dengan penelitian yang dilakukan oleh Puspaningrum (2017), Stacia \& Juniarti (2015), Putri (2016), Chen \& Lee (2017) dan Sabatini (2019) yang menunjukan bahwa Corporate Social Responsibility berpengaruh negatif pada nilai perusahaan. Dari uraian diatas terlihat ikonsistensi hasil dalam penelitian-penelitian sebelumnya dan menjadikan dorongan untuk diteliti kembali dengan menambahkan variabel moderasi.

Penelitian yang dilakukan oleh beberapa peneliti menunjukan hasil yang tidak konsisten yang kemungkinan diakibatkan adanya faktor lain yang mempengaruhi hubungan Corporate Social Responsibility (CSR) terhadap nilai perusahaan. Faktor yang mungkin dapat menambah nilai perusahaan dan juga perhatian investor, yaitu kinerja lingkungan. Kinerja lingkungan menjadi hal 
yang dapat mempengaruhi keputusan investor dalam menanamkan modalnya, karena dengan kinerja lingkungan yang baik dapat meningkatkan citra baik perusahaan.

Peringkat kinerja lingkungan yang baik menunjukkan bahwa perusahaan menunjukkan keseriusan dalam mengelola lingkungan hidup, sehingga perusahaan dinilai memiliki etika bisnis yang baik (Lingga, 2016). Kinerja lingkungan diharapkan dapat menjadi informasi sosial yang bernilai tambah yang dapat mempengaruhi persepsi investor untuk menanamkan modalnya pada perusahaan (Bahri \& Cahyani, 2017). Kinerja lingkungan diduga dapat memperkuat pengaruh pengungkapan Corporate Social Responsibillty (CSR) terhadap nilai perusahaan, dengan adanya pengungkapan Corporate Social Responsibility (CSR) dan disertai dengan peringkat kinerja lingkungan yang baik, maka investor akan semakin yakin untuk menanamkan modalnya. Sehingga dalam penelitian ini ditambahkan kinerja lingkungan sebagai pemoderasi.

Menurut Suratno dkk. (2006) dalam Kusuma \& Dewi (2019), kinerja lingkungan perusahaan (environmental performance) adalah kinerja perusahaan dalam menciptakan lingkungan yang baik (green). Penilaian kinerja lingkungan diukur dengan penilaian peringkat PROPER yang dilakukan oleh Kementerian Lingkungan Hidup. Tujuan dari penilaian tersebut adalah untuk meningkatkan kinerja perusahaan dalam pelestarian di bidang lingkungan. Program Penlilaian Peringkat Kinerja Perusahaan (PROPER) merupakan salah satu upaya Kementerian Lingkungan Hidup untuk memdorong perusahaan dalam pengelolaan lingkungan hidup melalui pengungkapan informasi (Lingga \& Wirakusuma, 2019). Program ini diharapkan dapat mendorong perusahaan untuk menaati peraturan perundang-undangan dan menerapkan cleaner production (www.menlh.go.id).

Sistem peringkat kinerja PROPER mencakup lima peringkat warna yaitu emas, hijau, biru, merah, dan hitam. Perusahaan dengan perolehan peringkat PROPER yang baik, merupakan hal positif yang dapat direspon oleh investor atau calon investor (Lingga \& Wirakusuma, 2019). Hal tersebut karena perusahaan dianggap telah melakukan pengelolaan lingkungan dengan baik dan secara konsisten menunjukan kenggulan lingkungan dalam proses produksi barang dan jasa. Kondisi ini diduga dapat mendorong peningkatan nilai perusahaan melalui kenaikan harga saham. Kinerja lingkungan diduga dapat memperkuat pengaruh Corporate Social Responsibility (CSR) pada nilai perusahaan.

Corporate Social Responsibility (CSR) di dalam penelitian ini diproksikan dengan Global Reporting Index (GRI) G4, sedangkan kinerja lingkungan diukur dengan Program Penilaian Peringkat Kinerja Perusahaan (PROPER). Penilaian PROPER dilakukan oleh Kementrian Lingkungan Hidup yang juga turut melibatkan masyarakat. Adapaun perbedaan anatara penelitian ini dengan penelitian Lingga \& Wirakusuma (2019)adalah penelitian yang dilakukan (Lingga \& Wirakusuma (2019) meneliti perusahaan sektor industri dasar dan kimia, aneka industri dan pertambangan tahun 2015 - 2017, sedangkan penelitian ini berfokus pada perusahaan sektor perkebunan kelapa sawit tahun 2014-2018. Alasan pemilihan sektor perkebunan sawit dikarenakan penggunaan lahan 
hutan oleh sektor ini memiliki dampak yang besar terhadap lingkungan maupun sosial (Greenpeace, 2018).

Teori Legitimasi menjelaskan bahwa apabila perusahaan mampu memperhatikan pengelolaan lingkunganya, maka keberadaan perusahaan yang memiliki citra yang baik akan direspon positif oleh masyarakat. Corporate Social Responsibility dilakukan perusahaan sebagai suatu bentuk tanggung jawab dan perhatian perusahaan pada masyarakat dan lingkungan, dengan cara menyisihkan sebagian keuntungannya untuk kepentingan masyarakat dan lingkungan sekitanya. Menurut Ghaesani, (2016), apabila perusahaan melakukan Corporate Social Responsibility (CSR) perusahaan akan memiliki citra yang baik sehingga akan lebih diminati oleh para investor.

Teori Stakeholder menjelaskan apabila perusahaan dapat memenuhi harapan para stakeholder, maka akan dapat meningkatkan nilai perusahaan. Semakin terpenuhinya semua keinginan stakeholder akan haknya seperti untuk mengetahui kinerja finansial, lingkungan, serta tanggung jawab sosialnya dapat menciptakan kepercayaan terhadap perusahaan. Meningkatnya kepercayaan stakeholder ini dapat meningkatkan nilai perusahaan, dikarenakan perusahaan tidak dapat terpisah dari keberadaan stakeholder.

Berdasarkan teori Sinyal, keputusan investasi pihak luar akan sangat bergantung pada informasi yang dikeluarkan perusahaan. Nilai perusahaan akan berkembang jika perusahaan memiliki insentif untuk mengungkapkan informasi yang bernilai tambah. Semakin sering perusahaan mengungkapkan tanggung jawab sosialnya yang merupakan informasi yang bersifat positif, maka pasar akan mereaksinya sebagai suatu keunggulan yang dimiliki perusahaan.

Hasil penelitian yang dilakukan oleh Rosiana et al., (2013), Retno \& Priantinah (2012), Nurani, (2015) menunjukkan bahwa Corporate Social Responsibility (CSR) berpengaruh positif terhadap nilai perusahaan. Apablia perusahaan melakukan Corporate Social Responsibility (CSR), maka perusahaan akan dapat meningkatkan image perusahaan dimata stakeholder, melalui respon positif dimata masyarakat. Adanya perhatian perusahaan terhadap lingkungan dan sosial, akan meningkatkan loyalitas konsumen terhadap perusahaan, yang secara tidak langsung dapat meningkatkan nilai perusahaan. Dengan demikian, semakin baik pengungkapan Corporate Social Responsibility (CSR) yang dilakukan oleh perusahaan maka akan meningkatkan nilai perusahaan. Berdasarkan uraian diatas, maka hipotesis penelitian ini adalah dirumuskan sebagai berikut.

$\mathrm{H}_{1}$ : Corporate Social Responsibility (CSR) berpengaruh positif pada nilai perusahaan.

Teori Kontijensi menjelaskan bahwa tujuan perusahaan tidak hanya untuk memenuhi kepentingan pemilik perusahaan saja dengan memaksimalkan laba, tetapi perusahaan juga harus memperhatikan kepentingan lain, seperti kepentingan masyarakat dan lingkungannya. Kinerja lingkungan merupakan bentuk perhatian perusahaan terutama kepada lingkungan, selain kegiatan CSR yang dilakukan. Menurut Handayati \& Rochayatun (2012), kinerja lingkungan adalah usaha perusahaan untuk melestarikan dan mewujudkan keselarasan antara kepentingan perusahaan dan keberlangsungan lingkungan. Hasil penelitian yang dilakukan Kusuma (2019) menunjukan hasil bahwa kinerja lingkungan berpengaruh positif pada nilai perusahaan. Semakin baik kinerja 
lingkungan yang dilakukan perusahaan maka citra perusahaan di mata masyarakat akan terlihat baik. Investor lebih tertarik berinvestasi pada perusahaan yang memiliki tanggung jawab yang baik terhadap lingkungan dan memiliki legitimasi dari masyarakat. Kinerja lingkungan sebagai variabel moderasi diduga dapat memperkuat hubungan Corporate Social Responsibility (CSR) dan nilai perusahaan. Kinerja lingkungan diharapkan menjadi informasi sosial yang mempengaruhi persepsi investor untuk menanamkan modal sehingga dapat meningkatkan nilai perusahaan. Berdasarkan uraian diatas, maka hipotesis penelitian ini adalah dirumuskan sebagai berikut.

$\mathrm{H}_{2}$ : Kinerja Lingkungan memperkuat pengaruh pengungkapan Corporate Social Resposibility (CSR) pada nilai perusahaan.

\section{METODE PENELITIAN}

Penelitian ini dilakukan pada perusahaan yang terdaftar di Bursa Efek Indonesia sektor pekebunan kelapa sawit yang menjadi peserta PROPER tahun 2014-2018 dengan mengakses situs http://idx.co.id, situs perusahaan dan situs www.menlh.go.id untuk mendapatkan informasi dan data yang diperlukan.

Obyek yang diteliti pada penelitian ini adalah kinerja lingkungan dan Corporate Social Responsibility (CSR) terhadap nilai perusahaan pada Bursa Efek Indonesia sektor perkebunan kelapa sawit tahun 2014-2018.

Populasi dalam penelitian ini adalah seluruh perusahaan di sektor perkebunan kelapa sawit yang terdaftar di Bursa Efek Indonesia periode tahun 2014-2018. Sampel yang digunakan dalam penelitian ini adalah perusahaan sektor perkebunan kelapa sawit yang terdaftar di Bursa Efek Indonesia yang dipilih melalui teknik purposive sampling dengan kriteria yang telah ditentukan.

Teknik analisis data yang digunakan dalam penelitian ini adalah Moderated Regression Analysis (MRA) dengan uji interaksi. Pengujian ini dilakukan untuk mengetahui pengaruh vaiabel moderasi terhadap variabel independen pada variabel dependen. Uji ini digunakan dengan pertimbangan akan dapat mengurangi dampak multikoliniearitas dan agar dapat memperoleh pengaruh yang lebih baik dari variabel independen pada variabel dependen. Moderated regression analysis dinyatakan dalam bentuk model persamaan sebagai berikut:

Keterangan:

$$
Y=\alpha+\beta_{1} X_{1}+\beta_{2} X_{2}+\beta_{3}\left|X_{1} \cdot X_{2}\right|+e
$$

Y = Nilai Perusahaan

a $\quad=$ Konstanta

$\beta_{1} \quad=$ Koefisien regresi variabel Pengungkapan CSR

$\beta_{2} \quad=$ Koefisien regresi variabel Kinerja Lingkungan

$\beta_{3} \quad=$ Koefisien regresi interaksi antara Pengungkapan CSR dengan Kinerja

Lingkungan

$\mathrm{X}_{1} \quad=$ Pengungkapan Corporate Social Responsibility

$\mathrm{X}_{2}=$ Kinerja Lingkungan

e $\quad$ error term

\section{HASIL DAN PEMBAHASAN}

Statistik deskriptif disajikan untuk memberikan informasi mengenai karakteristik variabel-variabel penelitian, yaitu jumlah sampel, nilai maksimum, nilai 
minimum, nilai rata-rata (mean), dan standar deviasi (deviation standard). Hasil statistik deskriptif penelitian ini dapat dilihat pada Tabel 1 berikut:

Tabel 1. Hasil Uji Statistik Deskriptif

\begin{tabular}{llllll}
\hline & N & Minimum & Maximum & Mean & $\begin{array}{l}\text { Std. } \\
\text { Deviation }\end{array}$ \\
\hline $\begin{array}{l}\text { Nilai Perusahaan (Y) } \\
\begin{array}{l}\text { Pengungkapan CSR } \\
\left(X_{1}\right)\end{array}\end{array}$ & 40 & 0,11 & 2,06 & 0,9968 & 0,38946 \\
$\begin{array}{l}\text { Kinerja Lingkungan } \\
\left(X_{2}\right)\end{array}$ & 40 & 3,00 & 0,26 & 0,1788 & 0,5135 \\
Valid N (listwise) & 40 & & 4,00 & 3,2250 & 0,42290 \\
\hline
\end{tabular}

Valid N (listwise) $\quad 40$

Sumber: Data Penelitian, 2019

Variabel nilai perusahaan yang diproksikan dengan Tobin's $Q$ menunjukan hasil bahwa sampel dalam penelitian berjumlah 40. Variabel nilai perusahaan $(Y)$ mempunyai nilai minimum 0,11 yaitu PT. Bakrie Sumatera Plantations Tbk. tahun 2018 dan nilai maksimum 2,06 yaitu PT. Astra Agro Lestari Tbk. tahun 2014. Mean (rata-rata) nilai perusahaan adalah 0,9968, yang berarti jika rasio $\mathrm{q}$ dibawah 1 menunjukan investasi dalam aset belum menghasikan laba yang bernilai tinggi. Standar deviasi nilai perusahaan adalah sebesar 0,38946 .

Variabel pengungkapan CSR yang diproksikan dengan CSRDI menunjukan hasil bahwa sampel dalam penelitian berjumlah 40. Variabel pengungkapan CSR $\left(X_{1}\right)$ memiliki nilai minimum adalah sebesar 0,10 yaitu pengungkapan CSR dari PT. PP London Sumatra Indonesia Tbk. tahun 2014. Nilai maksimum pengungkapan CSR adalah sebesar 0.26 yaitu pengungkapan CSR dari PT. Bakrie Sumatera Plantations Tbk. tahun 2015. Mean (rata-rata) dari pengungkapan CSR adalah 0,1788 menunjukan bahwa perusahaan perkebunan kelapa sawit yang terdaftar di BEI rata-rata mengungkapkan $17 \%$ atau sebanyak 5 item pengungkapan CSR dari 91 indikator pengungkapan CSR berdasarkan GRI G4. Standar deviasi pengungkapan CSR sebesar 0,05135.

Variabel kinerja lingkungan yang diprosikan dengan peringkat PROPER menunjukan hasil bahwa sampel dalam penelitian berjumlah 40. Variabel kinerja lingkungan $\left(\mathrm{X}_{2}\right)$ mempunyai nilai minimum sebesar 3,00 dan nilai maksimum sebesar 4,00. Mean (rata-rata) kinerja lingkungan adalah sebesar 3,2250, yang berarti bahwa masih banyak perusahaan sektor perkebunan kelapa sawit yang masih menerima peringkat PROPER warna biru.

Uji Moderated Regression Analysis (MRA) bertujuan untuk menguji interaksi antar variabel penelitian. Pengolahan data uji Moderated Regression Analysis (MRA) menggunakan program SPSS. Hasil dari uji Moderated Regression Analysis (MRA) disajikan dalam Tabel 2 berikut ini. 
Tabel 2. Hasil Moderated Regression Analysis

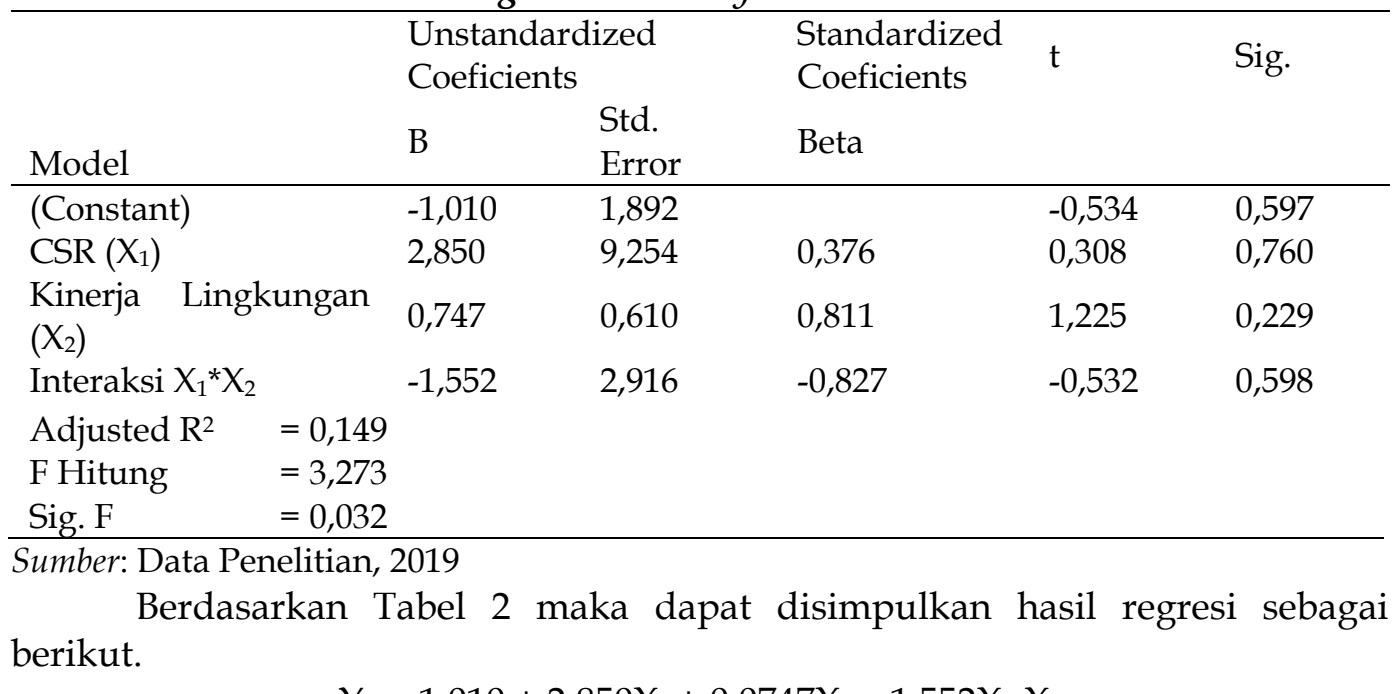

$$
\mathrm{Y}=-1,010+2,850 \mathrm{X}_{1}+0,0747 \mathrm{X}_{2}-1,552 \mathrm{X}_{1} \cdot \mathrm{X}_{2}
$$

Nilai konstanta sebesar $-1,010$ memiliki arti bahwa apabila pengungkapan CSR, kinerja lingkungan, dan hubungan pengungkapan CSR dengan kinerja lingkungan konstan, maka nilai perusahaan akan turun sebesar 1,010 persen. Nilai koefisien regresi CSR sebesar 2,850 memiliki arti bahwa apabila pengungkapan CSR meningkat sebesar 1 persen, maka nilai perusahaan akan meningkat sebesar 2,850 persen. Nilai koefisien regresi kinerja lingkungan sebesar 0,747 memiliki arti bahwa apabila kinerja lingkungan meningkat 1 persen, maka nilai perusahaan meningkat sebesar 0,747 persen. Nilai koefisien moderasi antara pengungkapan CSR dengan kinerja lingkungan memiliki nilai sebesar -1,552 yang artinya bahwa apabila interaksi pengungkapan CSR dengan kinerja lingkungan mengalami peningkatan 1 persen, maka nilai perusahaan akan menurun sebesar 1,552 persen dengan asumsi variabel independen lainnya konstan.

Koefisien determinasi $\left(R^{2}\right)$ diukur untuk mengetahui presentase pengaruh variabel independen terhadap perubahan variabel dependen. Pada Tabel 2 nilai adjusted $\mathrm{R}^{2}$ sebesar 0,149 atau 14,9 persen. Hal ini berarti bahwa 14,9 persen perubahan (naik/turun) pada nilai perusahaan dipengaruhi atau dijelaskan oleh pengungkapan CSR sedangkan sisanya 86,1 persen dijelaskan oleh faktor-faktor lain yang tidak dimasukkan ke dalam model.

Uji kelayakan model digunakan untuk mengetahui apakah model Moderated Regression Analysis (MRA) dalam penelitian ini layak digunakan. Pada Tabel 2 nilai $F$ hitung sebesar 3,273 dengan nilai signifikansi $F$ adalah sebesar 0,032. Nilai signifikansi $F$ tersebut lebih kecil dari level signifikansi 0,05 (F $\leq \alpha)$. Jadi dapat disimpulkan bahwa model Moderated Regression Analysis (MRA) layak digunakan.

Hasil pengujian menunjukan bahwa koefisien regresi pengungkapan CSR menunjukan hubungan positif, yang menunjukan bahwa semakin tinggi pengungkapan CSR maka akan meningkatkan nilai perusahaan, namun taraf signifikansi pengungkapan CSR yang lebih besar dari 0,05 menunjukkan bahwa 
pengungkapan CSR tidak berpengaruh pada nilai perusahaan. Hasil ini tidak sesuai dengan hipotesis yang diajukan sehingga $\mathrm{H}_{1}$ tidak diterima.

Pengungkapan CSR belum dapat menjadi indikator prioritas para investor atau stakeholder untuk berinvestasi pada suatu perusahaan. Menurut Sudarma (2017) besar atau kecilnya luas pengungkapan tanggung jawab sosial perusahaan tidak dapat mempengaruhi peningkatan nilai perusahaan. Ini berarti investor atau stakeholder memandang bahwa informasi yang diungkapkan oleh perusahaan belum relevan dan sesuai dengan kenyataan yang dilakukan oleh perusahaan. Semua perusahaan yang termasuk dalam sampel hanya memperhatikan kinerja keuangannya, dan cenderung mengesampingkan kinerja non-keuangan seperti tanggung jawab sosial perusahaan. Hal ini didukung dengan minimnya rata-rata jumlah item pengungkapan CSR yang diungkapkan oleh perusahaan dibandingkan dengan jumlah item yang seharusnya diungkapkan. Meskipun perusahaan sudah mengungkapkan CSR dengan maksimal, namun pada kenyataannya masih banyak permasalahan perusahaan kelapa sawit menyangkut lingkungan salah satunya adalah pembukaan lahan dengan cara membakar hutan. Pembukaan lahan baru dengan membakar hutan ini yang menimbulkan bencana kabut asap disekitar perkebunan kelapa sawit dan bahkan sampai ke Negara Malaysia, Singapura bahkan sampai Thailand (Suara.com, 2019). Walaupun perusahaan dalam sampel belum terbukti melakukan tindakan pembakaran hutan, namun hal ini dapat menyebabkan berkurangnya citra baik perusahaan dimata investor. Investor akan menilai bahwa pengungkapan CSR perusahaan tidak bisa dijadikan tolok ukur akan keberpihakan perusahaan kepada lingkungan dan masyarakat. Meskipun perusahaan sudah mengungkapan tanggung jawab sosialnya namun pada kenyataan masih banyak kasus kebakaran hutan di sekitaran perkebunan kelapa sawit mengakibatkan ketidakpercayaan investor akan pengungkapan CSR yang diterbitkan perusahaan.

Menurut Stacia \& Juniarti (2015) naik atau turunya nilai perusahaan tidak dipengaruhi oleh pengungkapan CSR, ini berarti bahwa investor atau stakeholders lebih tertarik dengan manfaat secara langsung dari perusahaan daripada investasi jangka panjang dibidang lingkungan. Temuan ini sejalan dengan Romana (2017) dan Sudarma \& Darmayanti, (2017) yang menyatakan bahwa Corporate Social Responsibility (CSR) tidak memiliki pengaruh yang signifikan pada nilai perusahaan. Jadi terdapat kriteria lainnya yang menjadi pertimbangan investor atau stakeholder dalam menanamkan modalnya. Perusahaan dengan pengungkapan CSR yang tinggi belum dapat menjamin nilai perusahaan yang tinggi juga. Hal ini bertolak belakang dengan teori sinyal yang menyatakan bahwa semakin banyak pengungkapan informasi yang bernilai positif oleh perusahaan, maka investor atau stakeholder akan cenderung memilih untuk berinvestasi pada perusahaan tersebut. Informasi yang dikeluarkan perusahaan (dalam bentuk pengungkapan CSR) tidak dapat menyakinkan kepada investor atau stakeholder, bahwa perusahaan sudah melakukan tanggung jawab sosial dan lingkungannya. Dilihat dari teori Legitimasi juga tidak mendukung hasil penelitian ini yang dimana, teori ini menyatakan bahwa perusahaan akan mengungkapkan CSR dengan maksimal agar memperoleh legitimasi dari staketolder, masyarakat maupun pemerintah, namun dalam kenyataannya 
pengungkapan CSR oleh perusahaan masih sangat minim. Oleh sebabnya maka investor atau stakeholder merasa tidak diperhatikan oleh perusahaan yang mengakibatkan menurunnya tingkat kepercayaan stakeholder kepada perusahaan yang berimplikasi pada menurunnya nilai perusahaan. Disisi lain meskipun perusahaan sudah berusaha mengungkapkan kinerja finansial dan tanggung jawab sosialnya kepada para stakeholder, namun hal ini tidak dapat meningkatkan nilai perusahaan. Hal ini berbeda dengan esensi dari teori Stakeholder, yang menyatakan bahwa semakin banyak harapan stakeholder yang terpenuhi maka akan meningkatkan nilai perusahaan.

Hasil pengujian menunjukan bahwa kinerja lingkungan tidak berpengaruh dalam hubungan pengaruh pengungkapan CSR pada nilai perusahaan. Kinerja lingkungan belum mampu memoderasi hubungan antara pengungkapan CSR terhadap nilai perusahaan, ini berarti bahwa kinerja lingkungan tidak dapat memperkuat pengaruh pengungkapan CSR pada nilai perusahaan. Hasil ini tidak sesuai dengan hipotesis yang diajukan sehingga $\mathrm{H}_{2}$ tidak diterima.

Kinerja lingkungan yang diproksikan dengan PROPER belum dapat meningkatkan pengaruh penggungkapan CSR pada nilai perusahaan. Menurut Lingga \& Wirakusuma (2019) perusahaan yang mengikuti PROPER tidak dapat mempengaruhi perusahaan dalam mengungkapan CSR dalam meningkatkan nilai perusahaan. Sedangkan menurut Nurani (2015) tidak ada jaminan yang kuat bahwa dana lingkungan yang besar, besar pula program dan dampak dari pelaksanaan program lingkungan perusahaan tersebut dalam meningkatkan nilai perusahaan. Kinerja lingkungan tidak termasuk kedalam kriteria investor atau stakeholders untuk menanamkan modalnya ke perusahaan, dengan kinerja lingkungan yang baik belum dapat memberikan keuntungan finansial ataupun non-finansial bagi para investor atau stakeholders. Kinerja lingkungan tidak dapat meningkatkan pengungkapan CSR, dikarenakan PROPER yang diterbitkan oleh Kementerian Lingkungan Hidup tidak sesuai dengan pengungkapan CSR menurut Global Report Initiative Generation 4 (GRI G4). Temuan ini sejalan dengan penelitian yang dilakukan oleh Nurani (2015) dan Lingga \& Wirakusuma (2019) yang menyatakan bahwa kinerja lingkungan tidak memiliki pengaruh yang signifikan terhadap hubungan CSR dan nilai perusahaan.

Menurut Indrayanti et al., (2017) berdasarkan teori Kontijensi maka terdapat faktor situasional lain yang mungkin akan saling berinteraksi dalam suatu kondisi tertentu. Hasil penelitian ini bertentangan dengan teori Kontijensi yang dijelaskan sebelumnya, karena kinerja lingkungan tidak terbukti memoderasi pengaruh pengungkapan CSR pada nilai perusahaan. Hal ini dikarenakan PROPER tidak dapat meningkatkan citra perusahaan dan tidak ada manfaat secara langsung yang dirasakan oleh investor atau stakeholders (Lingga \& Wirakusuma, 2019).

\section{SIMPULAN}

Hasil penelitian menunjukan bahwa CSR tidak berpengaruh pada nilai perusahaan. Hal ini dapat disebabkan kurangnya perhatian investor terhadap pengungkapan CSR yang dilakukan perusahaan. CSR yang diungkapkan perusahaan tidak sejalan dengan kondisi yang terjadi. Investor dan calon 
investor tidak menjadikan pengungkapan CSR sebagai kriteria untuk berinvestasi, namum mereka memperhatikan kinerja keuangan perusahaan. Meskipun perusahaan mengungkapkan CSR dengan maksimal, namun jika perusahaan mengalami kerugian maka harga saham yang diperdagangkan akan turun. Pengungkapan CSR yang dilakukan belum dapat memberikan kepercayaan pada investor akan keberpihakan perusahaan terhadap lingkungan dan masyarakat, dapat diartikan juga bahwa penelitian ini belum mendukung teori Legitimasi, teori Stakeholder, dan teori Sinyal. Hasil penelitian ini menunjukan bahwa kinerja lingkungan tidak mampu memperkuat pengaruh pengungkapan CSR pada nilai perusahaan. Hal ini disebabkan item yang diungkapkan dalam PROPER berbeda dengan apa yang ada di pengungkapan CSR. PROPER hanya berfokus pada pengelolaan lingkungan saja, namun CSR juga mengungkapkan pengembangan masyarakat dan karyawan, pemberdayaan masyarakat dan keselamatan konsumen yang tidak tedapat dalam pengungkapan kinerja lingkungan. Kinerja lingkungan hanya mewakili sedikit dari pengungkapan CSR, hal ini berarti meskipun penilaian kinerja lingkungan perusahaan baik, belum tentu pengungkapan CSR tingi juga. Penelitian ini belum dapat mendukung teori Kontijensi yang menyatakan bahwa terdapat faktor lain yang dapat saling berinteraksi dalam mempengaruhi suatu kondisi tertentu.

Implikasi kebijakan bagi pihak perusahaan adalah bahwa perusahaan perlu merumuskan strategi dalam pengungkapan CSR seperti meningkatkan kesadaran, kinerja, fungsi, peran, wewenang, dan tanggung jawab. Perusahaan juga perlu menerapkan pedoman sebagai standar dalam melaksanakan dan mengungkapkan CSR yang sesuai dengan karakteristik perusahaan, lingkungan bisnis yang dihadapi serta dapat diterima dan direspon dengan baik oleh stakeholder.

Hasil penelitian ini dapat menjadi bahan pertimbangan bagi investor maupun calon investor dalam mengambil keputusan untuk berinvestasi dengan melihat pengungkapan CSR, nilai perusahaan, dan kinerja lingkungan sehingga tidak hanya terpaku pada ukuran-ukuran moneter. Konsistensi pengungkapan CSR dan peringkat kinerja lingkungan dapat menjadi pengawasan oleh investor terhadap tanggung jawab sosial dan lingkungan yang dilakukan oleh perusahaan.

\section{REFERENSI}

Bahri, S., \& Cahyani, F. A. (2017). Pengaruh Kinerja Lingkungan Terhadap Corporate Financial Performance Dengan Corporate Social Responsibility Disclosure Sebagai Variabel I Ntervening (Studi Empiris Pada Perusahaan Manufaktur Yang Terdaftar Di Bei). Ekonika: Jurnal Ekonomi Universitas Kadiri, 1(2), 117-142.

Chen, R. C. Y., \& Lee, C. H. (2017). The influence of CSR on firm value: an application of panel smooth transition regression on Taiwan. Applied Economics, 49(34), 3422-3434.

Ghaesani, N. S. (2016). Pengaruh Pengungkapan Corporate Social Responsibility, Profitabilitas, Ukuran Perusahaan dan Kinerja Lingkungan Terhadap Nilai Perusahaan. Jurnal Akuntansi Dan Investasi. 
Gundha, R. Kabut Asap Karhutla Indonesia Merembet Sampai ke Thailand. https://www.suara.com/news/2019/09/18/172033/kabut-asapkarhutla-indonesia-merembet-sampai-ke-thailand . Diakses pada 8 November 2016

Hadalfath, M. Penyebab Persengketaan Kelapa Sawit antara Indonesia dan Uni Eropa. $\quad$ https://kumparan.com/maulana-hadalfath/penyebabterjadinya-persengketaan-kelapa-sawit-antara-indonesia-dan-unieropa. Diakses pada 31 Agustus 2019.

Handayati, P., \& Sulis Rochayatun. (2012). The Effect of Environmental Performance and Corporate Governance Mechanism on the Corporate Social Responsibility Disclosure. International Journal of Business, Economics and Law, 8(1), 296-300.

Indrayanti, S. M. A., Suprasto, H. B., \& Astika, I. B. P. (2017). Pengaruh Kompetensi Pada Kinerja Auditor Internal Dengan Motivasi, Komitmen Organisasi Dan Ketidakpastian Lingkungan Sebagai Pemoderasi Inspektorat Kabupaten Tabanan. 11, 3823-3856.

Kusuma, I. M. E. W., \& Dewi, L. G. K. (2019). Pengaruh Kinerja Lingkungan pada Nilai Perusahaan dengan Good Corporate Governance Sebagai Variabel Pemoderasi Fakultas Ekonomi dan Bisnis Universitas Udayana ( Unud ), Bali , Indonesia PENDAHULUAN Era globalisasi di. E-Jurnal Akuntansi Universitas Udayana, 26(3), 2183-2209.

Lingga, V. P., \& Wirakusuma, M. G. (2019). Pengaruh Corporate Social Responsibility pada Nilai Perusahaan dengan Kinerja Lingkungan Sebagai Pemoderasi. E-Jurnal Ekonomi Dan Bisnis Universitas Udayana, $4,413$.

Nahda, K., \& Harjito, D. A. (2011). Pengaruh Corporate Social Responsibility terhadap Nilai Perusahaan dengan Corporate Governance sebagai Variabel Moderasi. Jurnal Siasat Bisnis, 15(1), 1-12.

Noerirawan, M. R., \& Muid, A. (2012). Pengaruh Faktor Internal Dan Eksternal Perusahaan Terhadap Audit Delay. Diponegoro Journal of Accounting, 1(1), 1-12.

Nurani, W. (2015). Pengaruh Pengungkapan Corporate Social Responsibility (CSR) Terhadap Nilai Perusahaan Dengan Kinerja Lingkungan dan Struktur Kepemilikan Modal Asing Sebagai Variabel Pemoderasi. 1(1), 1-15.

Puspaningrum, Y. (2017). Pengaruh Corporate Social Responsibility Dan ( Studi Empiris Pada Perusahaan Pertambangan Di Bursa Efek Indonesia ). Jurnal Profita, 2(1), 1-14.

Putri, A. K., Sudarma, M., \& Purnomosidhi, B. (2016). Pengaruh Corporate Social Responsibility terhadap Nilai Perusahaan dengan Ukuran Perusahaan dan Jumlah Dewan Komisaris sebagai Variabel Pemoderasi (Studi pada Perusahaan Manufaktur yang terdaftar Bursa Efek Indonesia). Jurnal Aplikasi Manajemen, 14(2).

Ratnadewi, P., \& Ulupui, I. G. K. A. (2016). Mekanisme Corporate Governance Sebagai Variabel Pemoderasi Pengaruh Pengungkapan Corporate Social Responsibility Pada Nilai Perusahaan. E-Jurnal Akuntansi, 14(1), 548-574. 
Retno, R. D., \& Priantinah, D. (2012). Pengaruh Good Corporate Governance Dan Pengungkapan Corporate Social Responsibility Terhadap Nilai Perusahaan (Studi Empiris Pada Perusahaan Yang Terdaftar Di Bursa Efek Indonesia Periode 2007-2010). Nominal, Barometer Riset Akuntansi Dan Manajemen, 1(2).

Risa, N., Sulastri, T., \& Pramono, J. (2011). CORPORATE SOCIAL RESPONSIBILITY PERUSAHAAN KEPADA MASYARAKAT Nurma Risa Tuti Sulastri Joko Pramono. Jrak, 2(2), 73-83.

Romana, S. (2017). Pengaruh Corporate Social Responsibility Terhadap Nilai Perusahaan Dengan Profitabilitas Sebagai Variabel Moderating (Studi Empiris Perusahaan Sektor Pertambangan yang Terdaftar di Bursa Efek Indonesia Periode 2011-2015). Jurnal Fakultas Ekonomi Prodi Akuntansi Universitas Pasir Pengaraian.

Rosiana, G. M. E., Juliarsa, G., \& Sari, M. M. (2016). Pengaruh Pengungkapan CSR Terhadap Nilai Perusahaan Dengan Profitabilitas Sebagai Variabel Pemoderasi. InFestasi, 12(1), 1.

Sabatini, K., \& Sudana, I. P. (2019). Pengaruh Pengungkapan Corporate Social Responsibility Pada Nilai Perusahaan Dengan Manajemen Laba Sebagai Variabel Moderasi. Jurnal Ilmiah Akuntansi Dan Bisnis, 14(1), 56-69.

Soraya, A. Greenpeace : Wilmar Internasional Biang Deforestasi di Indonesia. https://tirto.id/greenpeace-wilmar-internasional-biang-deforestasi-diindonesia-cZUD. Diakses pada 17 Maret 2019.

Stacia, E., \& Juniarti. (2015). Pengaruh Pengungkapan Corporate Social Responsibility terhadap Nilai Perusahaan di Sektor Pertambangan. Business Accounting Review, 3(2), 81-90. Retrieved from http://publication.petra.ac.id/index.php/akuntansibisnis/article/view/3852

Sudarma, I. K. G. A. M., \& Darmayanti, N. P. A. (2017). Pengaruh Csr, Kepemilikan Manajerial Dan Profitabilitas Terhadap Nilai Perusahaan Sektor Pertambangan Pada Indeks Kompas 100. E-Jurnal Manajemen Universitas Udayana, 6(4), 1906-1932.

Sujoko, \& Soebiantoro, U. (2017). Pengaruh Struktur Kepemilikan Saham, Leverage, Faktor Intern dan Faktor Ekstern Terhadap Nilai Perusahaan. EKUITAS (Jurnal Ekonomi Dan Keuangan), 11(2), 236. 